\title{
CZY POLSKA PSYCHOLOGIA MA SWOJĄ HISTORIĘ? RÓŻNE OBLICZA HISTORII PSYCHOLOGII
}

\begin{abstract}
STRESZCZENIE
Uzasadnieniem dla pytania w tytule artykułu jest to, że w okresie I wojny światowej, Polska nie posiadała samodzielnej państwowości. Tym samym, polska psychologia nie mogła brać udziału w działaniach militarnych. Pomimo to, mogła w dwóch uniwersytetach (Kraków oraz Lwów) rozwijać się jako dyscyplina akademicka. Natomiast w zaborze rosyjskim rozpoczął się rozwój psychologii jako dyscypliny praktycznej (organizacja psychologów - PTP, troska o dzieci „specjalnej” troski - Szyc, Grzegorzewska). Już na początku XX wieku, na terenach, które niebawem miały się stać ponownie polskie, rozwój psychologii odbywał się w języku polskim i służył pokojowym celom (wychowanie, produkcja) przyszłego, samodzielnego Państwa. A to znaczy, że przed, w trakcie i po zakończeniu I wojny światowej, w odróżnieniu od innych „psychologii europejskich”, psychologia polska istniała i rozwijała się w celach wyłącznie pokojowych.
\end{abstract}

Słowa kluczowe: historia psychologii i jej modele, historia myśli psychologicznej, psychologia empiryczna i eksperymentalna, psychologia w kontekstach religijnych oraz ideologicznych, zapis oraz interpretacja, brentanizm w Monarchii Austro-Węgierskiej

\section{Does history of Polish psychology exist? MULTIPLE FACETS OF THE HISTORY OF PSYCHOLOGY}

\section{Abstract}

The reason for the question in the title is that during the First World War, Poland was not an independent country so there was no official Polish psychology contribution in the war effort. Nevertheless, psychology was allowed to be developed at two universities (Cracow and Lvov) as an academic discipline. On the other hand, in the areas under Russian jurisdiction the development of psychology started as a practical discipline (organization of psychologists - Polish Psychological Society, care for children with special needs - Szyc, Grzegorzewska). In the areas that would soon become Polish again, as early as at the beginning of the $20^{\text {th }}$ century, psychology was being developed in Polish language and it served exclusively peaceful purposes (education, manufacturing) for the future independent state. That means, that as opposed to other "European

$1 \quad$ Adres do korespondencji: wlzeidler@gmail.com. 
psychologies" before and after the First World War, Polish psychology did exist and was developed strictly for peaceful purposes.

Keywords: history of psychology and their models, history of psychological thought, empirical and experimental psychology, psychology in religious and ideological contexts, record and interpretation, brentanism in Austrian-Hungarian monarchy

Powyższy tytuł stanowi trawestację zdania rozpoczynającego tekst Zarysu Psychologii Hermanna Ebbinghausa (1910). W tym samym tekście (s. 22-23) wyraził pogląd, że psychologia stała się nauką wówczas, kiedy jej potencjał został skierowany na problemy własnego rozwoju, zgodnie z obowiązującymi wówczas kryteriami naukowości. W tym rozumieniu status nauki był warunkiem wejścia do historii. I tworzenia własnej historii. Była to propozycja interesująca, ale komplikowała sytuację na kilka różnych sposobów. O to, czy i w jakim sensie psychologia jest nauką, toczono spory jeszcze przez wiele lat. Dopiero po 50 latach Herbert Feigl (1962) znalazł odpowiedź zadowalającą: tak, psychologia jest nauką, ponieważ potrafi fakty wyjaśniać lub interpretować i dokonywać predykcji.

Jednak niebawem ta sama psychologia stała się przedmiotem krytyki ze strony rewolucji studenckiej roku 1968. Podstawą krytyki młodzieży studenckiej była refleksja społeczno-historyczna. Twierdzono, że psychologia jest narzędziem wspierającym interesy burżuazji. To niezwykłe odkrycie i radykalne sformułowanie miały instrumentalizować psychologię dla potrzeb tej ideologii, która po gorzkich doświadczeniach II wojny światowej, próbowała sobie podporządkować umysłowość obywateli Europy Zachodniej. Ta sama ideologia „pod sztandarami postępu i naukowości” zniewalała życie społeczne i naukowe Europy Wschodniej już od momentu zakończenia II wojny światowej. Przy tym, de facto, redukowała psychologię do formuły nauk przyrodniczych, na poziomie fizjologii. Tym samym „ideologiczna recepta” uprawiania psychologii okazała się sprzeczna z diagnozą Herberta Feigla, albowiem brakowało w niej miejsca dla interpretacji. Błąd ideologii polegał na tym, że redukowała ona lub wręcz zamykała psychologię w kręgu nauk przyrodniczych, ignorując znane i godne uwagi próby klasyfikacji nauk Heinricha Rickerta (1863-1936) oraz Wilhelma Windelbanda (1848-1915).

Wyzwaniem dla psychologów w tzw. krajach socjalistycznych stało się teraz zapotrzebowanie na konstrukcję, która byłaby w stanie połączyć w jedną całość realia nauk przyrodniczych z ideologią ustroju. Zadanie to postanowiła wykonać sama psychologia, posługując się szczególnym rodzajem „interpretacji”, polegającej na przyklejaniu stosownych, tzn. ideologicznie poprawnych, etykiet. Nic dziwnego, że psychologowie stracili zainteresowanie dla historii swojej nauki, która zaczęła wychodzić im naprzeciw w coraz to innym ideologicznym 
kostiumie. Dalsze informacje na temat kłopotów polskiej psychologii w tym okresie znajdzie Czytelnik w innych publikacjach, których przykładami są artykuły Zofii Ratajczak (2011) i Teresy Rzepy (2013).

Podobnie jak z uzasadnieniem walorów psychologii jako nauki, twórcy psychologii mieli też kłopoty z opisaniem i uzasadnieniem samodzielności swojej nauki. Dla Wilhelma Wundta (1913) oderwanie psychologii od filozofii było rzeczą trudną do pomyślenia! Zwolennicy psychologii eksperymentalnej mieli najczęściej zdanie przeciwne. W tej kwestii odmienne stanowisko reprezentował Wolfgang Köhler (1958), który dostrzegał potrzebę współpracy interdyscyplinarnej i dlatego pisał:

[...] te pełne szczęścia momenty w historii nauki pojawiają się wówczas, kiedy fakty, które traktowane dotychczas jako jedynie pojedyncze zjawiska, nagle w połączeniu z pozornie odległymi, innymi faktami, ukazują się nam w całkowicie nowym świetle [...] wychodzenie poza zastane granice jest jedną z najbardziej efektywnych metod uprawiania nauki (Köhler, 1958, s. 91, tłum. W.Z.)

Jakby antycypując sugestie Wolfganga Köhlera, już na progu XX wieku Hugo Münsterberg (1863-1916) postulował powołanie do życia psychologii społecznej jako odrębnej (w zakresie przedmiotu oraz metod) dyscypliny psychologicznej. Jego postulat zrealizowali bracia Floyd oraz Gordon Allport. Niebawem psychologia społeczna stała się dyscypliną odrębną i samodzielną na tyle, że zaczęła pisać własną historię.

Oczywiście nie opisaliśmy jeszcze całego spektrum odmian psychologii. Na przełomie wieków XIX i XX pojawiło się jeszcze kilka dalszych „konwencji”, które także zabiegały o miejsce w „salonie nauk”: psychoanaliza, psychotechnika, charakterologia. Wolfgang Martynkiewicz (2009) przedstawił interesujące, ale niepokojące przykłady tworzenia się w latach 20. i 30. XX wieku związków niektórych odmian psychologii z powstającymi właśnie strukturami władzy zarówno w ideologii, jak i polityce. Były to tylko niektóre spośród możliwych dróg, które prowadziły do instytucjonalizacji, a zaraz potem, w następnym kroku, do instrumentalizacji psychologii. Niektóre $\mathrm{z}$ tych dróg należały do uczęszczanych już podczas I wojny światowej, inne podczas drugiej, a jeszcze inne także po jej zakończeniu.

W tym miejscu należy jeszcze zauważyć, że w rozmaitych okresach historycznych i w różnych krajach związki psychologii z otaczającą ją rzeczywistością, tzn. z czasem i lokalizacją oraz systemem społecznym, były zarówno wyraźne, jak i zróżnicowane, a jej historię zapisywano w różnych konwencjach. Jest rzeczą zrozumiałą, że niejednorodne było także zainteresowanie psychologią i jej historią. Znajdowało to wyraz w tworzeniu nowych wzorów (sposobów) zajmowania się albo wręcz uprawiania historii psychologii (por. Zeidler, 2003). Helmut Lück (2008) wyróżnił cztery modele jej uprawiania: historię wielkich mężów, historię 
idei, historię problemów, historię społeczną. Przypomnieć należy również, że po okresie słabego zainteresowania historią psychologii, albo niechęci do niej, nastawienie to uległo zmianie. Zastąpiły je ciekawość lub dociekliwość.

\section{ZAINTERESOWANIE HISTORIĄ PSYCHOLOGII}

Występowanie w życiu społecznym czynników obciążających funkcjonowanie psychiczne jednostek lub całych grup staje się przyczyną poszukiwania pomocy, także w psychologii. Takie nastawienie funkcjonuje w płaszczyźnie emocjonalnej, zainteresowanie historią psychologii ma natomiast raczej charakter poznawczy. Inicjuje je dysonans poznawczy. Czyli brak wiedzy albo dysponowanie wiedzą błędną lub przestarzałą. Wiemy, że szeroką - od USA aż do Europy - falę zainteresowania historią psychologii spowodowała 100. rocznica utworzenia tzw. psychologicznego laboratorium w Lipsku. Jej wpływy dotarły także do Polski i stały się dobrze widoczne, szczególnie już po załamaniu się komunistycznej dyktatury. W Polsce wynikiem i wyrazem tego wyzwolonego z ideologicznych więzów zainteresowania historią psychologii był znakomity podręcznik Ryszarda Stachowskiego (2000), którego walory - ze względu na specyfikę ujęcia przedmiotu zainteresowania (historia myśli psychologicznej) oraz uniknięcie płycizn interpretacyjnych - przewyższają przypisywane podręcznikowi E.G. Boringa A History of Experimental Psychology (1950, wyd. II; por. Zeidler, 2003, s. 58-60).

Drugim - w tym kontekście: niezwykle wartościowym - dziełem jest praca Teresy Rzepy i Bartłomieja Dobroczyńskiego (2009): Historia polskiej myśli psychologicznej. Szczególny walor tej pracy stanowi to, że jej autorzy zastąpili poszukiwanie „obcych” elementów w polskiej psychologii przez ukazanie specyfiki historii polskiej myśli psychologicznej, i osobliwość tę odważyli się zaprezentować w sposób wyrazisty. Konsekwencje tych sukcesów znalazły wyraz m.in. we wzroście zainteresowań czytelniczych historią psychologii. Obok nich nastąpiła intensyfikacja prac badawczych w zakresie historii psychologii polskiej przy dostrzeganiu jej związków z rozwojem psychologii europejskiej. Swoistą nowość stanowiło to, że szereg naukowych spotkań (m.in. konferencje), jak i publikacje były realizowane przy próbie współpracy polsko-niemieckiej. Wyniki funkcjonowania tego nurtu zostały zaprezentowane na dwóch konferencjach naukowych w Warszawie (2009 i 2011, Wyższa Szkoła Finansów i Zarządzania) oraz w kilku publikacjach naukowych (Zeidler, 2009; Zeidler, Lück, 2011; Herrmann, Zeidler, 2012). Można sądzić, że niezwykle interesująca seria wydawnicza $\mathrm{Na}$ drogach i bezdrożach historii psychologii, która ukazuje się w Lublinie od roku 2011 pod redakcją Teresy Rzepy i Cezarego W. Domańskiego (2011), stanowi kolejny etap zaspokajania zainteresowań historią psychologii. A w ten sposób rzecz traktując, należałoby powiedzieć, że od początku XXI wieku w Polsce panuje żywe zainteresowanie (zarówno badawcze, jak i czytelnicze) historią 
psychologii, ze szczególnym uwzględnieniem tych obszarów, które w okresie panowania komunizmu były albo omijane, albo „zakazane”. Dodajmy, że ów sposób uprawiania historii psychologii w Polsce ulega sukcesywnym zmianom, dzięki czemu można powiedzieć, że obok prac „faktograficznych” coraz częściej pojawiają się także publikacje o wyraźnym nastawieniu na interpretację we właściwym kontekście społecznym i politycznym (np. Gołąb, 2015; Hryniewiecka, 2015; Izdebski, 2015).

Już ten krótki opis rozwoju zainteresowań historią psychologii w Polsce pozwala sobie wyobrazić rozmiary i znaczenie tej problematyki, skoro zdecydujemy się rozpatrywać ją w szerszym kontekście: europejskim lub kontynentalnym. Do tej pory opis i analiza historii psychologii ograniczały się do historycznych i politycznych granic wybranego kraju (Anglia, Niemcy, USA, Polska). Tymczasem, zgodnie z podanym wcześniej cytatem, „wychodzenie poza zastane granice jest jedną $\mathrm{z}$ najbardziej efektywnych metod uprawiania nauki" (Köhler, 1958, s. 91). W odniesieniu do historii psychologii, także polskiej psychologii, wskazanie Wolfganga Köhlera wydaje się zarówno słuszne, jak i niezwykle trudne. Kłopoty zaczynają się już wtedy, kiedy próbujemy ocenić stan posiadania psychologii $\mathrm{w}$ danym momencie oraz określonym kraju, respektując przy tym zaistniałe powinowactwa lub osobliwości. Wydaje się, że uporządkowanie historii psychologii według nacji, kontynentów lub szkól jest możliwe tylko w sposób powierzchowny, według zasady, którą Lück nazwał historią wielkich mężów. Próby znalezienia bardziej wyszukanych zasad podziału mogą się kończyć niepowodzeniem, takim, które ograniczyło wartość dzieła Abrahama A. Robacka ${ }^{2}$ (1970). W jego „światowej historii psychologii”, opublikowanej w oryginale w roku 1961, przy wszystkich krajach, które do I wojny światowej nie miały samodzielności państwowej, brak jest wzmianki na temat psychologii. Czy można zatem sądzić, że na terenie wszystkich trzech zaborów psychologia nie była znana? A jeżeli „jakaś” już funkcjonowała, czy mogła to być psychologia polska?

\section{CZY ISTNIALA PSYCHOLOGIA EUROPEJSKA?}

Bardziej niż błąd Robacka, uzasadniony nieznanymi względami, na uwagę zasługuje rzeczywisty stan rzeczy. Warto zatem uwzględnić pewne realia, które w perspektywie europejskiej muszą być lepiej widoczne niż wówczas, gdy chcemy je dostrzec „z drugiej strony Oceanu”. Powstaje bowiem pytanie, czy w okresie trwania zaborów (a to była „polska specyfika”), na ich terenie, psychologia mogła już być „polską”, tzn. czy posługiwała się językiem polskim jako narzędziem wyrażania własnych poglądów i tworzenia własnych teorii? Oczywiście funkcjonowanie danej nauki w języku narodowym poszerza jej dostępność

2 Dokładniejszy obraz jego twórczości podaję w pracy: Zeidler, 2011, s. 47-48. 
w danym narodzie, a tym samym: zainteresowanie jej treściami. Max Dessoir (1902) podkreślił, że proces tworzenia własnej, niemieckojęzycznej terminologii psychologicznej był dziełem trzech pokoleń niemieckich psychologów. Specyfikę tego procesu w odniesieniu do języka polskiego przedstawili Rzepa i Dobroczyński (2009) oraz Panczyk i Zeidler (2011). W Polsce osiąganie „terminologicznej tożsamości" następowało w okresie trwania zaborów, w sposób, dla każdego z zaborów, odmienny i specyficzny. Przyjąć zatem należy, że polska psychologia, czyli ta, która prowadziła swoje badania w języku polskim i w tymże języku wyrażała ich wyniki, istniała już przed wybuchem I wojny światowej. Dobrym przykładem może być praca Franciszki Baumgarten: Kłamstwo dzieci i młodzieży, o której będzie tutaj mowa w osobnym artykule.

Powróćmy jeszcze do tego, co nazwaliśmy „błędem Robacka”, czyli pominięcia przez niego znaczenia koncepcji Franza Brentana dla rozwoju i kształtu psychologii w Europie na przełomie wieków XIX i XX. W cytowanym już podręczniku historii psychologii wraca Stachowski (2000) do treści i roli poglądów Brentana wielokrotnie. Inni historycy psychologii traktują poglądy i znaczenie tego uczonego w sposób różnorodny. Norton Hunt (2007) ignoruje zarówno samego autora, jak i jego poglądy. W przeciwieństwie do niego Duane P. Schultz oraz Sydney E. Schultz (2008), również autorzy amerykańscy, zamieścili na dwóch stronach zwartą, ale udaną charakterystykę zarówno poglądów, jak i znaczenia Brentana dla rozwoju psychologii. Podkreślają to, że jego podstawowa praca, Psychologia z empirycznego punktu widzenia (1999), ukazała się po raz pierwszy w roku 1874, tzn. dokładnie w tym samym roku, w którym Wundt opublikował Grundzüge der physiologischen Psychologie. Te dwie prace miały wprawdzie odmienne, ale fundamentalne znaczenie dla dwóch różnych nurtów uprawiania „tworzącej się” właśnie nowej psychologii. Tej empirycznej (Brentano) oraz eksperymentalnej (Wundt). Ponadto Brentano stał się twórcą nowej orientacji teoretycznej, znanej jako psychologia aktów. Autorzy tego podręcznika nazywają Brentanę jednym z pionierów psychologii i uznają go za prekursora psychologii postaci i psychologii humanistycznej.

Pamiętać należy także o tym, że w interesującym nas okresie dziejów Europy, obok wydarzeń politycznych, gospodarczych, społecznych oraz militarnych, przemiany zachodziły także w nauce, owszem również w filozofii. A ta w ciągu XIX wieku ulegała modyfikacjom, o których Władysław Tatarkiewicz napisał: „Polska również w ciągu stulecia przerzucała się w swej filozofii z krańca na kraniec: zaczęła od pozytywizmu, po powstaniu listopadowym przeszła do metafizyki mesjanistycznej, by po powstaniu styczniowym wrócić do pozytywizmu" (Tatarkiewicz, 2001, s. 7). Te wszystkie przemiany, obojętnie, czy patrzymy na nie w perspektywie europejskiej czy polskiej, były wyjątkowo ważne, albowiem w każdej z nich były one „wieloczynnikowe”, tzn. z politycznymi współwystępowały militarne, z gospodarczymi naukowe itd. Oglądając w takiej, bardziej zróżnicowanej perspektywie owo znane „oddzielanie się” psychologii od filozofii, 
warto wziąć pod uwagę zarówno oblicze tej nowo tworzącej się psychologii, jak również owej „starej” filozofii, od której się już oddzieliła albo chciała się właśnie oddzielić. Osobliwość możliwych sytuacji ciekawi tym bardziej że w tym czasie, który nas interesuje, w różnych częściach Europy istniały lub dominowały odmienne orientacje filozoficzne. Okoliczność ta była psychologom znana już wtedy, kiedy zaczęły się kształtować pierwsze „orientacje” psychologiczne, tzn. wtedy, gdy pisali swoje podstawowe dzieła Wundt i Brentana. Obydwaj z zamiarem stworzenia nowych relacji między filozofią i psychologią. Ich zamiary były jednoznaczne, ale ich realizacje przyniosły różne wyniki. Brentano, odchodząc od filozofii spekulatywnej, stał się rzecznikiem psychologii empirycznej. Wundt, nastawiony „krytycznie” do filozofii francuskiej i angielskiej, a jednocześnie nawiązujący do reguł nauk przyrodniczych, stał się zwolennikiem psychologii eksperymentalnej. Taki obraz otrzymujemy przy spojrzeniu powierzchownym. Jego pogłębienie otrzymamy podczas lektury kontrowersyjnej pracy Wundta z roku 1915 Die Nationen und ihre Philosophie. Ein Kapitel zum Weltkrieg.

W tej pracy koncentruje się Wundt na trzech rodzajach zmiennych, które najpierw wyróżnia i charakteryzuje. Są to: filozofia, „narodowość” i religia. Druga spośród wymienionych okazuje się najmniej jednoznaczna i rozpływa się w grupie takich określeń jak: plemię, naród, społeczeństwo, imperium. Z kolei religia nakłada się na język i powoduje dalsze różnice. Tym samym twórca psychologii eksperymentalnej, oprócz filozofii „Francuzów” i „Anglików”, względnie jednolitej, natrafia na kłopoty z filozofią „Niemców”. Niemieckojęzycznych było wówczas w Europie kilka narodów, przy tym różniły się one pod względem wyznania. Były zatem narody katolickie i protestanckie. To był fakt, który nabierał dużego znaczenia, kiedy na terenie psychologii należało uzgodnić poglądy na temat kwestii ontologicznych, teorii poznania i metodologii. Spośród trzech zaborców Polski dwóch miało polskiej psychologii „cos’” do zaoferowania, ale były to także koncepcje różne. Ta jedna pozostawała w zgodzie $\mathrm{z}$ wyznaniem katolickim, ta druga z protestanckim. Jeżeli uwzględnimy kilka realiów politycznych, charakterystycznych dla końcowej fazy rozbiorów, to zrozumiemy, że - w Polsce - większym zainteresowaniem cieszyła się ta koncepcja, która była bliższa katolicyzmowi. A to znaczy, że psychologia empiryczna Brentana była dla mentalności polskiej łatwiej „dostępna” niż inne orientacje.

Uproszczeniem byłoby jednak twierdzenie, że tylko religia decydowała o większej dostępności psychologii Brentana dla polskiej mentalności. Istotną rolę odgrywały tutaj także czynniki polityczne i organizacyjne, tzn. bardziej liberalny stosunek do polskiej tradycji oraz organizacji w zaborze austriackim. Przede wszystkim wyraźniejsza obecność języka polskiego w codziennym i kulturalnym życiu społeczeństwa w tym zaborze. I jako jego konsekwencja obecność polskiej nauki w oficjalnym systemie nauk, akceptowanym w tym zaborze. W roku 1986, nakładem Uniwersytetu Wiedeńskiego, ukazało się opracowanie na temat ostatnich 100 lat jego historii. Zawiera ono kilka szczegółów, które 
dobrze ilustrują ten interesujący nas problem. Po ostatnim z zaborów „ocalały” dwa polskie uniwersytety: Kraków (rok zał. 1364) oraz Lwów (rok zał. 1661). Obydwa zgermanizowano, a dopiero po roku 1867 nastąpiła ich stopniowa repolonizacja, „Zakończona” w roku 1879 dekretem, który stwierdzał, że językiem „urzędowym” w Uniwersytecie Lwowskim jest język polski. W roku akademickim 1884/1885 było w nim immatrykulowanych 976 studentów, a w roku 1913 5206 studentów. W Uniwersytecie Jagiellońskim w roku akademickim 1884/1885 było immatrykulowanych 871, a w roku 1913 - 2605 studentów. Przypomnę, że Kazimierz Twardowski, po objęciu profesury we Lwowie, niektóre ze swoich dzieł tłumaczył na język polski. Był to proces podobny do tego, o jakim pisał Dessoir: polegał na tłumaczeniu „dzieł łacińskich” na narodowy język niemiecki. Kilka dalszych, ważnych informacji na temat funkcjonowania psychologii w Austriackim Imperium znajdziemy w pracach Gerharda Benetki ${ }^{3}$ (1995, 2009), który przypomina, że okres działalności dydaktycznej Franza Brentana w Uniwersytecie Wiedeńskim obejmowal „zaledwie” 20 lat: 1874-1894. Kolejne 28 lat w dziejach Wiedeńskiej Psychologii (tzn. do objęcia dyrekcji Instytutu przez Karla Bühlera) cechowały wielokrotne zmiany orientacji (zarówno naukowych, jak i społecznych oraz politycznych), które nie sprzyjały ani ochronie, ani rozpowszechnianiu poglądów Brentana w tym Uniwersytecie.

Nadal jednak utrzymywało się zainteresowanie jego Psychologia z empirycznego punktu widzenia (1999). Poglądy Brentana, dzięki aktywności jego uczniów, uległy bowiem rozpowszechnieniu na terenie dawnej Monarchii Austro-Węgierskiej. Kazimierz Twardowski jest tutaj dobrym przykładem, ale nie jedynym. Równie szerokie, i także w nurcie poglądów Brentana, było oddziaływanie Antona Marty z Uniwersytetu w Pradze (por. Antonelli, 2011). Wyczerpanie tego tematu w ramach tego opracowania nie jest możliwe. Dlatego ograniczę się do zwrócenia uwagi na to, że rozpad owej podwójnej monarchii miał nader negatywny wpływ na dalsze zainteresowanie poglądami Franza Brentana. Restytucję tego zainteresowania można stwierdzić dopiero pod koniec XX wieku (por. Rzepa, Galewicz, Benetka, Antonelli ${ }^{4}$ ). W Polsce umniejszanie lub wręcz ignorowanie znaczenia poglądów Brentana było w okresie panowania komunizmu uwarunkowane przez ideologię. Tymczasem kształtowanie się polskiej psychologii i filozofii w okresie zaborów i później, już w okresie międzywojennym, a także ich kształt - wolny od związków z „brentanizmem” - są nie do pomyślenia.

3 Prof. Dr Gerhard Benetka (ur. 1962) jest dyrektorem Instytutu Psychologii Uniwersytetu im. Zygmunta Freuda w Wiedniu. Zajmuje się teoretycznymi podstawami psychologii, metodologią badań oraz historią psychologii.

4 Prof. Dr Mauro Antonelli (ur. 1962) jest profesorem uniwersytetów w Mediolanie oraz w Grazu. Przedmiotem jego zainteresowania jest historia psychologii europejskiej, ze szczególnym akcentem na psychologię Franza Brentana oraz Szkołę w Grazu. W roku 2016 ukazał się pierwszy numer „European Yearbook of the History of Psychology”, którego jest inicjatorem i redaktorem naczelnym. 


\section{DygResJa POLITYCZNA}

Zazwyczaj wybór języka wykładów uniwersyteckich miał uzasadnienie polityczne. W przypadku Monarchii Austro-Węgierskiej obowiązywały jednak inne tradycje oraz zwyczaje. Trzeba zatem zauważyć, że uniwersytety w Krakowie i Lwowie „posiadały” język polski, ale pomimo to Polska nie istniała jako państwo samodzielne. I ta właśnie okoliczność ograniczała możliwość udziału „Polski” w I wojnie światowej. Dopiero pod koniec wojny, w punkcie 13 pokojowej deklaracji Prezydenta Wilsona z dnia 8 stycznia 1918 roku, pojawił się plan restytucji polskiego państwa ${ }^{5}$. Restytucja oznaczała - jeszcze przed podpisaniem układu w Wersalu (10 stycznia 1920 roku) - konieczność tworzenia od nowa wszystkich instytucji niezbędnych dla funkcjonowania życia społecznego, gospodarczego i politycznego. O psychologii było już wiadomo, że ma istotne znaczenie dla życia umysłowego i gospodarczego. W zakresie wychowania i kształcenia, a także w odniesieniu do efektywności produkcji.

Tymczasem ze względu na brak samodzielności państwowej żaden $\mathrm{z}$ trzech zaborów nie mógł być, i nie był, stroną w I wojnie światowej. To zaś znaczy, że w sposób logicznie konieczny polska psychologia nie mogła być narzędziem pomocnym $w$ prowadzeniu wojny przez państwo, które przecież w tym okresie nie istniało! Musimy zatem przyjąć, że mimo posiadania narodowej świadomości polska psychologia mogła zacząć funkcjonować w sposób zinstytucjonalizowany dopiero $\mathrm{w}$ ramach nowych struktur państwowych: niepodległego państwa polskiego. W rzeczywistości jednak restytucja polskiego państwa mogła rozpocząć się dopiero po podpisaniu układu w Wersalu (10 stycznia $1920 \mathrm{roku}$ ), a to oznaczało konieczność tworzenia od nowa wszystkich instytucji niezbędnych dla funkcjonowania państwa jako organizmu społecznego, gospodarczego i politycznego.

Plan pokojowy Prezydenta Wilsona z dnia 8 stycznia 1918 roku, pkt XIII. „An independent Polish state should be erected which should include the territories inhabited by indisputably Polish populations, which should be assured a free and secure access to the sea, and whose political and economic independence and territorial integrity should be guaranteed by international covenant”. (pl. Internet): „Stworzenie niepodległego państwa polskiego na terytoriach zamieszkanych przez ludność bezsprzecznie polską, z wolnym dostępem do morza, niepodległością polityczną, gospodarczą, integralność terytoriów tego państwa ma być zagwarantowana przez konwencję międzynarodową". Te same treści pojawiły się rok wcześniej, w „orędziu” Wilsona z dnia 22 stycznia 1917 roku. Występujący w angielskim oryginale termin „should be erected” nie jest dokładnym odpowiednikiem terminu „restytucja”. Jednak, respektując historyczne realia, należy zgodzić się z tym, że Prezydent Wilson miał na myśli ówczesne realia polityczno-organizacyjne, upadek monarchii oraz imperiów, które oznaczały nic innego jak odzyskanie stanu niepodległości. Stąd wydaje się, że uwzględniając historyczne realia, w języku polskim, jest uzasadnione stosowanie terminu „restytucja”. 


\section{KŁOPOTY Z REKONSTRUKCJA DZIEJÓW POLSKIEJ PSYCHOLOGII}

Kiedy mówimy o historii, o historii psychologii lub historii polskiej psychologii, należy respektować odmienność rzeczywistych wydarzeń (dzieje) od ich zapisu oraz interpretacji. Szczególnej uwagi wymaga ta ostatnia okoliczność. Każdy fragment dziejów jest elementem w strukturze innej, większej całości. Dwie spośród nich są szczególnie ważne. Tę pierwszą nazywamy narodem, tę drugą państwem. Historia zna szereg dowodów na to, że nie są to struktury jednoznacznie i na zawsze od siebie oddzielone. Juan J. Linz (2009) pokazał cały szereg przyczyn i rodzajów zacierania się granic między tymi strukturami oraz ich degeneracji w kierunku reżimów totalitarnych. Jego praca uświadamia szereg deformacji w procesie dziejów - w procesie tworzenia się i przekształcania Europy. Nie trzeba dowodzić, że Polska uczestniczyła w tych przemianach od czasów średniowiecza. $Z$ jednej strony można obserwować umacnianie się poczucia narodowej tożsamości, a z drugiej - polskiej państwowości: ich kolejne sukcesy, zagrożenia lub wręcz porażki. Okresem szczególnie trudnym był okres rozbiorów. Wieki XVIII i XIX były w Europie okresem przemian wszystkich zasad oraz struktur życia społecznego, umysłowego, gospodarczego i politycznego. Każda z nich zachodziła w oparciu o dwa różne substraty. Tym pierwszym było poczucie narodowej tożsamości, zakorzenione w określonej kulturze, tym drugim - państwowość. Specyfika dziejów Europy w tym okresie obejmowała, jako jedną ze swoich cech charakterystycznych, dominację struktur państwowych i podporządkowanie im, czy wręcz ograniczenie, samodzielności struktur narodowych, najczęściej na zasadzie przemocy i gwałtu. Stosownym przykładem będzie tutaj przymus pobierania nauk w języku zaborcy. Tam, gdzie językiem urzędowym był język zaborcy, zapisywanie i publikowanie dziejów własnej nacji było utrudnione lub wręcz niemożliwe.

Nic dziwnego, że utrudnione było również zapisywanie i upowszechnianie historii polskiej psychologii, a jej interpretacja kłopotliwa. Kiedy Władysław Heinrich i Kazimierz Twardowski pisali swoje znakomite prace doktorskie i habilitacyjne na uniwersytetach zagranicznych (por. Panczyk, Zeidler, 2011), czy był to dorobek psychologii polskiej czy niemieckojęzycznej? Ryszard Stachowski (2011) przypomniał dzieło Jana Wł. Dawida - pierwszy polski kwestionariusz do badania umysłowości polskich dzieci, opracowany i opublikowany w roku 1886! W roku 1912 Franciszka Baumgarten (1927) prowadziła oryginalne badania nad kłamstwem dzieci w szkole rosyjskiej, ale w języku polskim! A w roku 1990 Helmut Hildebrandt i Eckart Scheerer ocenili nader wysoko wkład Władysława Heinricha do teorii badań nad uwagą i apercepcją - jego pracę w języku niemieckim, Die moderne physiologische Psychologie in Deutschland, z roku 1895 (por. Heinrich, 1988).

Oczywiście, nie jest ani moim zadaniem, ani celem dalsze wskazywanie przykładów obecności polskich psychologów w psychologii europejskiej. Dowodem na istnienie polskiej psychologii w okresie zaborów, już jako aktywności zbiorowej, 
jest także działalność dwóch towarzystw naukowych: Polskiego Towarzystwa Psychologicznego (Warszawa 1907 - Celińska, 2009) oraz Polskiego Towarzystwa Badań nad Dziećmi (Warszawa 1907 - Sprawozdanie, 1908). Każde z nich miało swój udział w powstaniu i rozwoju polskiej psychologii, najpierw w okresie zaborów, a później także w kolejnych okresach dziejowych kataklizmów, które stanowiły zagrożenie zarówno dla polskiej państwowości, jak i narodowej, a może po prostu: kulturowej tożsamości.

\section{ROZPAD I ODRODZENIE: NIEOCZEKIWANE KONSEKWENCJE WIELKIEJ WOJNY}

W bardzo solidnej monografii historycznej, Puszka Pandory, Jörg Leonhard (2014, s. 460 i nn.) zauważył, że poświęcenie i ofiary życia wielu tysięcy żołnierzy podczas I wojny światowej na froncie zachodnim upamiętniają pomniki pielęgnowane $z$ najwyższym szacunkiem i starannością. Natomiast jeszcze liczniejszych ofiar w bitwach na froncie wschodnim nie przypominają żadne monumenty. Tylko czy są one rzeczywiście potrzebne? Jest przecież tak, że te wszystkie okrutne ludzkie ofiary na froncie wschodnim dokumentują wydarzenia polityczne, być może ważniejsze od tych, o których Horacjusz pisał: monumentum aere perennius... - wydarzenia, które były bezpośrednim następstwem Wielkiej Wojny, a przyniosły wielu narodom wyzwolenie z imperialnego poddaństwa. Leonhard ma na myśli powstanie lub odrodzenie szeregu państw narodowościowych, uprzednio należących do "poddanych” jednego z tych imperiów, które w wyniku la Grande Guerre właśnie się rozpadły. Współczesna historiografia, zamiast zajmować się coraz bardziej mozolnym ustalaniem przyczyn i winnych, jest skłonna utrzymywać - wbrew poglądom wcześniejszym ${ }^{6}$ - że $\mathrm{w}$ rzeczywistości Wielka Wojna przede wszystkim zamykała jeden $\mathrm{z}$ rozdziałów europejskiej historii ${ }^{7}$ W wielu krajach Europy dawne monarchie zaczęła zastępować demokracja ${ }^{8}$, to zaś implikowało zmiany dwojakiego rodzaju. Z jednej strony rozpadały się dotychczasowe potężne organizmy państwowe, wręcz całe imperia! Z drugiej strony ich miejsce zajmowały państwa znacznie mniejsze, które powstawały dzięki odzyskaniu dawnej wolności i samodzielności. W odniesieniu do tożsamości państwowej: miejsce gwałtu i przemocy zajęło poczucie

6 Na przykład F. Fischer (1961). Owo wcześniejsze spojrzenie było respektowane także w literaturze psychologicznej, np. E. Scheerer (1989).

7 Por. np. Hans Herzfeld (1991), Erster Weltkrieg und Friede von Versailles.

8 Juan J. Linz definiuje demokrację następująco: „Wir nennen dann ein politisches System demokratisch, wenn es bei Wahrung der Grundrechte auf Vereinigungs-, Informations- und Kommunikationsfreiheit die freie Formulierung politischer Präferenzen erlaubt“ (2009, s. 12). „Dany system polityczny nazywamy demokratycznym, jeżeli przy poszanowaniu podstawowych praw do gromadzenia się i stowarzyszania, wymiany informacji i komunikacji umożliwia swobodne formułowanie politycznych preferencji” (tłum. W.Z). 
narodowej tożsamości (chyba właśnie to, które analizował Wilhelm Wundt w swojej Völkerpsychologie), niezwykle ważne. Jeżeli ówczesna psychologia miałaby do powiedzenia na temat wojny coś „własnego”, to chyba to, że z ustalaniem narodowej tożsamości największe trudności musiały mieć dawne imperia, w których dotychczas najwyższą wartością była idea państwa wielonarodowego oraz imperialnego! Nic dziwnego, że tu i ówdzie, w różnych okresach poczucie narodowej tożsamości budowane według „wzorców” państwa imperialnego prowadziło w kierunku radykalnego nacjonalizmu. W pracy Juana Linza (2009) rozpoznajemy go pod różnymi maskami, w kostiumie coraz to nowych reżimów totalitarnych i autorytarnych. Można powiedzieć, że zredukowana do aspektów politycznych, idea ta zachowała żywotność do naszych czasów. A nawet więcej: w różnych okresach bywała siłą napędową tego, co nazywamy biegiem historii (por. Th. Herrmann, W. Zeidler, 2012).

\section{RóżNE OBLICZA PSYCHOLOGII (?)}

W opracowaniach tego zeszytu spotykamy wielokrotnie tych samych „aktorów”: historię oraz psychologię. Tę pierwszą - raczej jako zapis lub przypomnienie dziejów, a tylko sporadycznie jako ich interpretację. Powiedzmy też, że psychologia w okresie Wielkiej Wojny, pomimo znaczących postępów w rozwoju, nie była w stanie zmienić biegu wydarzeń, nie zawsze była też należycie przygotowana, aby sprostać kierowanym pod jej adresem oczekiwaniom. Dodać jednak trzeba, że psychologia tego okresu, chociaż obecna w nauce, $\mathrm{w}$ działaniach politycznych i społecznych, nie była jeszcze tworem jednolitym. Oprócz tej akademickiej istniały także - poszukujące drogi ku swojej instytucjonalizacji - psychoanaliza oraz psychotechnika9. I ta pierwsza, i ta druga były skłonne uwzględnić potrzeby oraz zadania wynikające z toczących się działań wojennych. Poza tym było i tak, że psychologia akademicka, skoncentrowana wówczas na badaniach eksperymentalnych $\mathrm{w}$ laboratoriach, nie była w stanie zaspokoić wymagań będących konsekwencją wojennego krajobrazu. Być może pewnym niedopatrzeniem psychologów, a później także historyków psychologii było pojmowanie psychologii akademickiej w sposób jednostronny - jako nauki przyrodniczej.

Tymczasem jeszcze przed rozpoczęciem wielkiej wojny pojawiła się inna orientacja, która znalazła wyraz w sporze Diltheya z Ebbinghausem. Orientacja ta, sama uwikłana w sprzecznościach swojego czasu, zamiast wyjaśniać, usiłowała bieg konkretnych wydarzeń zrozumieć! Ale nie tylko ona. Być może należy tutaj przypomnieć także ten rodzaj narracji w odniesieniu do toczącej się la Grande Guerre, który Scheerer (1989) nazwał wojenną publicystyką.

9 Dodatkowe interesujące szczegóły na temat „urozmaicenia”, znaczenia i swoistego „,bogactwa” aktualnych pozaakademickich nurtów psychologii lat dwudziestych XX wieku w Niemczech przedstawił Wolfgang Martynkiewicz (2009). 
Autor ten lokował wszystkie publikacje opatrzone publicystycznym tytułem Kriegspsychologische poza granicami pojmowanej naukowo psychologii, która wówczas wolno i z pewnym trudem zdobywała dopiero „ostrogi prawdziwej nauki". Nie było bowiem żadnych gwarancji, że opracowania z owym Kriegspsychologische w tytule miały jeszcze coś wspólnego z psychologicznym dyskursem. Julia Barbara Köhne (2014) określiła takie opracowania jako fachliche und belletristische Kriegspublizistik. Opatrzone w tytule przymiotnikiem psychologiczne, budowały swoje treści na gruncie zdrowego rozsądku, jednak nie opierały się na wynikach psychologicznych badań naukowych. Ich publicystyczna atrakcyjność miała zastępować naukowe kompetencje.

\section{DROGA W PRZYSZLOŚĆ: KU EUROPEJSKIEJ TOŻSAMOŚCI?}

Autorki i Autorzy prac zamieszczonych w tym zeszycie skłonni są traktować la Grande Guerre jako kolejny etap w procesie rozwoju historii Europy. Z drugiej strony, przebieg oraz wyniki tej wojny są traktowane ze świadomością tego - co zauważyła już Franziska Baumgarten ${ }^{10}$ - jako swoiste wyzwanie dla psychologii (za: Daub, 2011, s. 225). Selekcja rekrutów lub opieka nad żołnierzami po urazach to były zadania, które zlecała psychologii polityka państw imperialnych $\mathrm{w}$ trakcie wojny. Zupełnie inaczej wyglądały jednak te zadania, które miała do wykonania psychologia po zakończeniu wojny dla potrzeb nowo powstałych państw narodowych, także dla niepodległego państwa polskiego. Było to budowanie zasad własnej, narodowej pedagogiki, kształcenie ogólne i zawodowe oraz wykorzystanie psychotechniki (Baumgarten, 1928/1930).

Być może przekonanie, że la Grande Guerre w rzeczywistości zamykała jeden z okresów politycznego i kulturowego rozwoju Europy, jest propozycją heurystycznie bardziej wartościową, niż się to początkowo wydaje. Dla nowych państw, które szukały drogi ku swojej przyszłości, odzyskanie wolności i samodzielności było nagrodą za trudy i ofiary poniesione w wojnie w cudzym interesie. Wolność była jednak niczym innym jak wyzwaniem i zadaniem: poszukiwaniem narodowej tożsamości w krajobrazie i klimacie XX wieku. Oczywiście przy udziale politycznej świadomości, ale też z wykorzystaniem dostępnych nauk. Czy psychologia była jedną z nich? Czy psychologia na początku XX wieku miała „tytuł” oraz odpowiednie narzędzia, aby dowolnej jednostce ludzkiej wyjaśnić, czym jest „naród”, a czym „państwo”?

10 „Die Zeit des 1. Weltkrieges war eine Fermentzeit für die angewandte Psychologie. In jedem kriegsführenden Lande gab es das gleiche Problem: wie... erringt man den Sieg über die Feindesmacht...“. „Okres I-szej wojny światowej, był dla psychologii stosowanej czasem niepokoju. W każdym kraju prowadzącym wojnę występował ten sam problem: jak... można zwyciężyć nieprzyjaciela..." (za: Daub, 2011, s. 225, tłum. W.Z.). 
Jest to okoliczność ważna, jeśli zaczniemy się zastanawiać nad instytucjonalizacją polskiej psychologii akademickiej. W rzeczywistości proces ten był możliwy jeszcze przed odzyskaniem niepodległości - w dwóch uniwersytetach (w Krakowie i we Lwowie), psychologia miała prawo w swojej działalności naukowej i dydaktycznej posługiwać się językiem polskim. W naszym zeszycie Teresa Rzepa i Ryszard Stachowski ukazują tworzenie w Polsce podstaw psychologii akademickiej na przykładach dokonań Kazimierza Twardowskiego i Stefana Błachowskiego. Twardowski tworzył filozofię i psychologię na bazie dawnego polskiego uniwersytetu we Lwowie, wszakże w oparciu o aktualną, nowoczesną psychologię Franza Brentana z Wiednia. Błachowski, w oparciu o wiedzę i doświadczenia $z$ uniwersytetów we Lwowie, Wiedniu i Getyndze, w nowym uniwersytecie w Poznaniu - formułował podstawy takiej psychologii, która chciała być europejską. Aby uniknąć zacierania prawdy, należy dodać, że obydwaj: Błachowski oraz Twardowski budowali swoją psychologię w bezpośrednim kontakcie z psychologią niemiecką. Ze względów historycznych była ona wówczas i tą najbliższą, i tą „najlepszą”.

$\mathrm{Na}$ terenie dawnego zaboru rosyjskiego sytuacja psychologii była trudniejsza. Pomimo to jednostki aktywne, które zdobyły wykształcenie poza granicami zaboru, działając pod wpływem specyficznych idei „pozytywizmu warszawskiego”, starały się wprowadzić psychologię do życia społecznego. To dzięki nim już w roku 1907 w Warszawie zostało założone Polskie Towarzystwo Psychologiczne (Celińska, 2009). Również w Warszawie, już od roku 1908, działało Polskie Towarzystwo Badań nad Dziećmi - inspirujące, inicjujące i sprawujące opiekę nad badaniami psychologicznymi nad dziećmi, które już za kilka lat miały się stać wolne od zniewolenia. Paweł Izdebski, na przykładzie postaci Anieli Szyc, przedstawia w naszym zeszycie szereg szczegółów na temat psychologii dziecka w Kraju, w którym dzieci w szkole nie mogły się posługiwać własnym językiem. Autor miał także okazję ujawnić świadectwo swoistej solidarności Anieli Szyc z Franciszką Baumgarten. Solidarność ta przejawiła się w roku 1912, kiedy to Franciszka Baumgarten planowała prowadzenie swoich badań nad kłamstwem dzieci i młodzieży w Łodzi w roku 1912 (sic!) w języku polskim! Historię i znaczenie tej pracy opisuje w osobnym artykule Włodzisław Zeidler.

Dopełnienie całości obrazu, albo zarys jego złożoności, prezentuje artykuł Cezarego Domańskiego. Poznajemy w nim „konsekwencje” działań wojennych: pacjentów psychiatrycznych, przed chwilą jeszcze żołnierzy dumnej armii austro-węgierskiej, hospitalizowanych w Lublinie pod opieką Viktora Tauska, lekarza armii c. k., o orientacji psychoanalitycznej.

Wszystkim Autorkom i Autorom dziękuję za współpracę w przygotowaniu tego zeszytu. Gorące słowa podziękowania kieruję pod adresem Prof. dra hab. Henryka Gasiula, Redaktora Naczelnego „Studia Psychologica”, który zachęcał wszystkich Autorów do pracy nad przygotowaniem numeru, a w chwilach trudnych podtrzymywał na duchu. 
Szczególną nagrodą za pracę całego zespołu Autorów będzie to, gdy zebrane w zeszycie opracowania zwiększą zainteresowanie Czytelników i staną się zachętą do dalszych badań nad historią psychologii europejskiej.

Włodzisław Zeidler Hohenwestedt, w lutym 2016.

\section{Bibliogr AFIA}

Antonelli, M. (2011). Die Deskriptive Psychologie von Anton Marty. Wege und Abwege eines Brentano-Schülers. W: M. Antonelli, J.C. Marek (red.), Anton Marty, Deskriptive Psychologie (s. 11-83). Würzburg: Verlag Königshausen \& Neumann. Antonelli, M., Marek, J.C. (red.). (2011). Anton Marty. Deskriptive Psychologie. Würzburg: Verlag Königshausen \& Neumann.

Baumgarten, F. (1927). Kłamstwo dzieci i młodzieży. Warszawa: „Nasza Księgarnia" Spółki Akc. Związku Nauczycielstwa Szkół Powszechnych.

Baumgarten, F. (1928). Die Berufseignungsprüfung. Theorie und Praxis. München: Oldenbourg. [Wydanie polskie: Baumgarten, F. (1930). Badanie uzdolnień zawodowych. Lwów-Warszawa: Książnica-Atlas].

Benetka, G. (1995). Psychologie in Wien. Wiedeń: WUV-Universitätsverlag. Benetka, G. (2009). Wiedeński Instytut Psychologii w okresie międzywojennym. Studia Psychologica, 9, 167-178.

Brentano, F. (1999). Psychologia z empirycznego punktu widzenia. Warszawa: Wydawnictwo Naukowe PWN. Przekład i wstęp Włodzimierz Galewicz.

Brett, G.S. (1969). Historia Psychologii (opr. R.S. Peters). Warszawa: Państwowe Wydawnictwo Naukowe.

Celińska, K. (2009). Powstanie i początki działalności Polskiego Towarzystwa Psychologicznego. W: W. Zeidler (red.), Psychologia europejska $w$ okresie międzywojennym (s. 61-76). Warszawa: VIZJA PRESS \& IT.

Daub, E. (1996). Franziska Baumgarten: Eine Frau zwischen akademischer und praktischer Psychologie. Frankfurt am Main: Peter Lang.

Daub, E. (2011). Franziska Baumgarten-Tramer: Für die Wissenschaftlichkeit praktischer Psychologie. W: S. Volkmann-Raue, H.E. Lück (red.), Bedeutende Psychologinen des 20. Jahrhunderts (s. 223-234). Wiesbaden: Springer VS Verlag für Sozialwissenschaften. (Tł. na polski: Daub, E. (2015). Franziska Baumgarten-Tramer: o naukowość psychologii praktycznej. W: S. Volkmann-Raue, H.E. Lück (red.), Najwybitniejsze kobiety w psychologii XX wieku (s. 269-282), (tł. W. Zeidler). Sopot: GWP).

Dessoir, M. (1902/reprint 1964). Geschichte der Neueren Deutschen Psychologie. Amsterdam: Verlag E.J. Bonset.

Ebbinghaus, H. (1910). Abriss der Psychologie. Leipzig: Verlag von Veit \& Comp. 
Feigel, H. (1962). Philosophical Embarrassment of Psychology. Psychologische Beiträge, 6(3-4), 340-364.

Fischer, F. (1961). Griffnach der Weltmacht. Die Kriegszielpolitik des kaiserlichen Deutschland 1914/1918. Düsseldorf: Droste.

Galewicz, W. (1999). Brentana anatomia życia psychicznego. W: F. Brentano, Psychologia z empirycznego punktu widzenia (s. 13-65). Warszawa: Wydawnictwo Naukowe PWN.

Gołąb, A. (2015). Alina Szemińska: niedoceniona odkrywczyni. W: S. Volkmann-Raue, H.E. Lück (red.), Najwybitniejsze kobiety w psychologii XX wieku (s. 363-385). Sopot: GWP.

Heinrich, W. (1988). U podstaw psychologii i inne pisma. Warszawa: PWN.

Herrmann, Th., Zeidler, W. (red.). (2012). Psychologen in autoritären Systemen. Frankfurt am Main: Peter Lang.

Herzfeld, H. (1991). Erster Weltkrieg und Friede von Versailles. W: G. Mann (red.), Propyläen Weltgeschichte. IX (s. 75-127). Berlin, Frankfurt am Main: Propyläen Verlag.

Hildebrandt, H., Scheerer, E. (1990). Einleitung. W: H. Hildebrandt, E. Scheerer (red.), H. Münsterberg: Frühe Schriften zur Psychologie (s. 11-48). Berlin, New York: Springer-Verlag.

Hoeres, P. (2004). Krieg der Philosophen. Die deutsche und britische Philosophie im Ersten Weltkrieg. Paderborn, München, Wien, Zürich: Verlag Ferdinand Schöningh.

Hryniewiecka, A. (2015). Maria Grzegorzewska: psychologia wobec niepełnosprawności. W: S. Volkmann-Raue, H.E. Lück (red.), Najwybitniejsze kobiety w psychologii XX wieku (s. 341-362). Sopot: GWP.

Hunt, M. (2007). The Story of Psychology. New York: AnchorBooks.

Izdebski, P. (2015). Józefa Joteyko: testy psychologiczne. W: S. Volkmann-Raue, H.E. Lück (red.), Najwybitniejsze kobiety w psychologii XX wieku (s. 321-340). Sopot: GWP.

Köhler, W. (1958). Dynamische Zusammenhänge in der Psychologie (org. ang. Dynamics in Psychology - 1940). Bern, Stuttgart: Verlag Hans Huber.

Köhne, J.B. (2014). Papierne Psychen. Zur Psychographie des Frontsoldaten nach Paul Plaut. W: U. Heikaus, J.B. Köhne (red.), Krieg! Juden zwischen den Fronten 1914-1918 (s. 65-104). München: Jüdisches Museum München.

Leonhard, J. (2014). Die Büchse der Pandora. Geschichte des Ersten Weltkrieges. München: Verlag C.H. Beck.

Linz, J.J. (2009). Totalitäre und autoritäre Regime. Potsdam: WeltTrends.

Lück, H. (2008). Historia Psychologii: orientacje, szkoły, kierunki rozwoju. Warszawa: VIZJA PRESS \& IT.

Martynkiewicz, W. (2009). Salon Deutschland. Geist und Macht 1900-1945. Berlin: Aufbau Verlag.

Panczyk, P., Zeidler, W. (2011). Jak powstawała polska naukowa terminologia psychologiczna: koncepcja abstrakcji Kazimierza Twardowskiego. W: W. Zeidler, 
H. Lück (red.), Psychologia europejska w okresie międzywojennym: sylwetki, osiagnięcia, przykłady (s. 245-270). Warszawa: VIZJA PRESS \& IT.

Ratajczak, Z. (2011). Nauka Pawłowa a polska psychologia. W: T. Rzepa,

C. W. Domański (red.), Na drogach i bezdrożach historii psychologii (s. 205228). Lublin: Wydawnictwo UMCS.

Roback, A. (1970). Weltgeschichte der Psychologie und Psychiatrie. Olten und Freiburg im Breisgau: Walter Verlag (tł. K. Thiele-Dohrmann). Org.: History of Psychology and Psychiatry (1961).

Rzepa, T. (1997). Psychologia w szkole lwowsko-warszawskiej. Warszawa: Wydawnictwo Naukowe PWN.

Rzepa, T. (2013). W poszukiwaniu ideologicznego piętna. W: T. Rzepa, C. W. Domański (red.), Na drogach i bezdrożach historii psychologii (s. 193208). Lublin: Wydawnictwo UMCS.

Rzepa, T., Dobroczyński, B. (2009). Historia polskiej myśli psychologicznej. Warszawa: Wydawnictwo Naukowe PWN.

Scheerer, E. (1989). Kämpfer des Wortes: Die Ideologie deutschen Psychologen im Ersten Weltkrieg und ihr Einfluß auf die Psychologie der Weimarer Zeit. Psychologie und Geschichte, 1(3), 12-22.

Schultz D.P., Schultz, S.E. (2008). Historia wspótczesnej psychologii. Kraków: Wydawnictwo UJ.

Sprawozdanie (1908). Sprawozdanie Polskiego Towarzystwa badań nad dziećmi. Warszawa: Drukarnia Naukowa.

Stachowski, R. (2000). Historia współczesnej myśli psychologicznej. Od Wundta do czasów najnowszych. Warszawa: Wydawnictwo Naukowe SCHOLAR.

Stachowski, R. (2011). Pierwszy polski kwestionariusz psychologiczny. W: W. Zeidler (red.), Kwestionariusze w psychologii. Postępy, zastosowania, problemy (s. 139-160). Warszawa: VIZJA PRESS \& IT.

Tatarkiewicz W. (2001), Historia Filozofii, T. III. Filozofia XIX wieku i wspótczesna. Warszawa: Wydawnictwo Naukowe PWN.

Wundt, W. (1913). Die Psychologie im Kampf ums Dasein. Leipzig: Kröner.

Wundt, W. (1915). Die Nationen und ihre Philosophie. Ein Kapitel zum Weltkrieg. Leipzig: Alfred Kröner Verlag.

Zeidler, W. (2003). O różnych sposobach uprawiania historii psychologii. Edukacja Humanistyczna, 1-2, 49-63.

Zeidler, W. (red.). (2009). Psychologia europejska w okresie międzywojennym. Warszawa: VIZJA PRESS \& IT.

Zeidler, W. (2011). Kwestionariusze w psychologii: kierunki rozwoju i pierwsze filiacje teoretyczne. W: W. Zeidler (red.), Kwestionariusze w psychologii. Postępy, zastosowania, problemy (s. 15-78). Warszawa: VIZJA PRESS \& IT.

Zeidler, W., Lück, H. (red.). (2011). Psychologia europejska w okresie międzywojennym. Sylwetki, osiagnięcia, problemy. Warszawa: VIZJA PRESS \& IT. 